\title{
11. From Open Fale to Mission Houses: Negotiating the Boundaries of "Domesticity" in Samoa
}

\author{
Latu Latai \\ The Australian National University
}

\section{The Samoan fale: Architecture, kinship and continuities in social relations}

The traditional Samoan fale or house is a magnificent feat of Samoan architecture. Its intricate design involves specialised knowledge and skills that are passed down from generation to generation. Significantly, the architecture of the Samoan fale is more than just a building. Its design mirrors and constitutes the culture and life of Samoan people being deeply connected to the values of kinship, ancestral past, land and community. The spaces outside and inside of the fale are pivotal to cultural form, ceremony and ritual. Moreover, architectural concepts are incorporated in Samoan proverbs, oratory and metaphors, and linked to other art forms in Samoa, such as boat building and tattooing. ${ }^{1}$

Fale is the Samoan word for all types of houses from small to large. In general it is characterised by an oval or circular shape, with wooden posts holding up a domed roof. There are various forms of the fale depending on its uses. There is generally a fale tele or big house which is the main house, usually in the front and centre of the family's ancestral land. This is where the matai or holder of the family's chiefly title resides. It is a central place for the family where meetings, worship and other ceremonies like funerals and bestowal of chiefly titles are held. Scattered behind the fale tele are the smaller houses of various households of kin. Behind them are the cooking houses where meals are prepared.

\footnotetext{
1 The use of Samoan architectural patterns is seen in the art of tattooing where they represent the person's ancestral and genealogical connections. Canoe patterns are also a central motif in male traditional tattoo which symbolises the young men's ability to serve their families. As Albert Wendt writes, tattooing in Samoa is "not just beautiful decoration, they are scripts-texts-testimonies to do with relationships, order, form, and so on." Albert Wendt, "Afterword: tatauing the post-colonial body," in Inside Out: Literature, Cultural Politics, and Identity in the New Pacific, ed. Vilsoni Heneriko and Rob Wilson, Lanham: Rowman \& Littlefield Publishers, 1999, pp. 399-412, p. 403.
} 


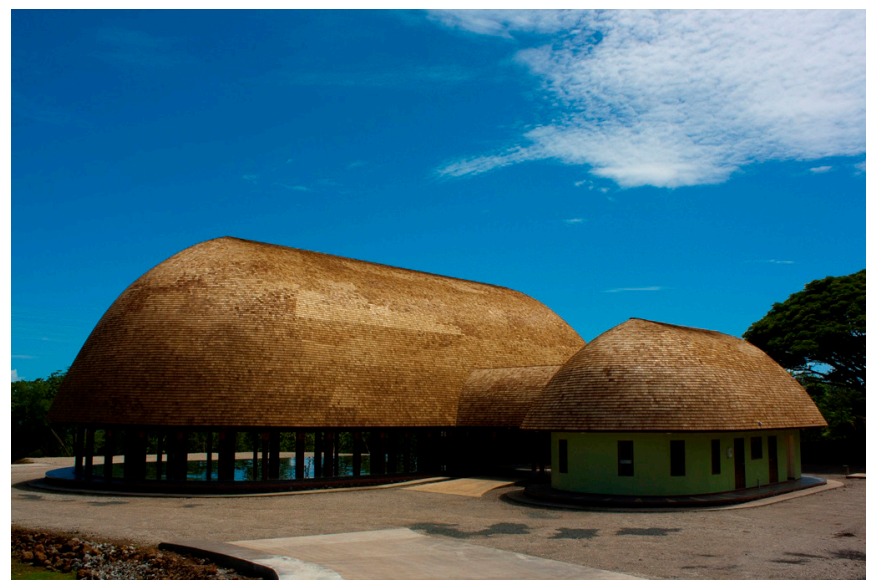

\section{Figure 27. A modern version of a traditional Samoan fale recently constructed at the National University of Samoa}

Source: Multimedia Unit, National University of Samoa.

The fale tele is usually the most elaborate in design and its construction often involves all members of the family and broader assistance from the village community. The tufuga fau fale, or the master builder oversees the entire building project. The domed framework constructed by men is made up of long dried strips of flexible coconut and breadfruit wood. The roof is then thatched with dried sugar cane or palm leaves woven by women. The framework is then supported by posts of hard wood, usually with three in the middle and the rest surrounding the house. The whole house is then lashed and tied together with plaited sennit rope called afa, handmade from dried coconut fibres. The afa is woven tight in complex patterns around the wooden frame and binds the entire construction together. Blinds, woven from coconut leaves, surround the house and can be pulled up during the day and down at night, depending on the weather. This allows for the free flow of air which is ideal in a tropical climate, and the free flow of people of the family. The foundation of the house is made of rocks and coral with the floor covered with smooth pebbles gathered from the river. These are covered by mats woven from the leaves of the coconut and pandanus trees. $^{2}$

2 Detailed descriptions of Samoan fale can be found in works done by UNESCO, The Samoan Fale, Apia: UNESCO Office for the Pacific States and UNESCO Principal Regional Office for Asia and the Pacific, 1992. 


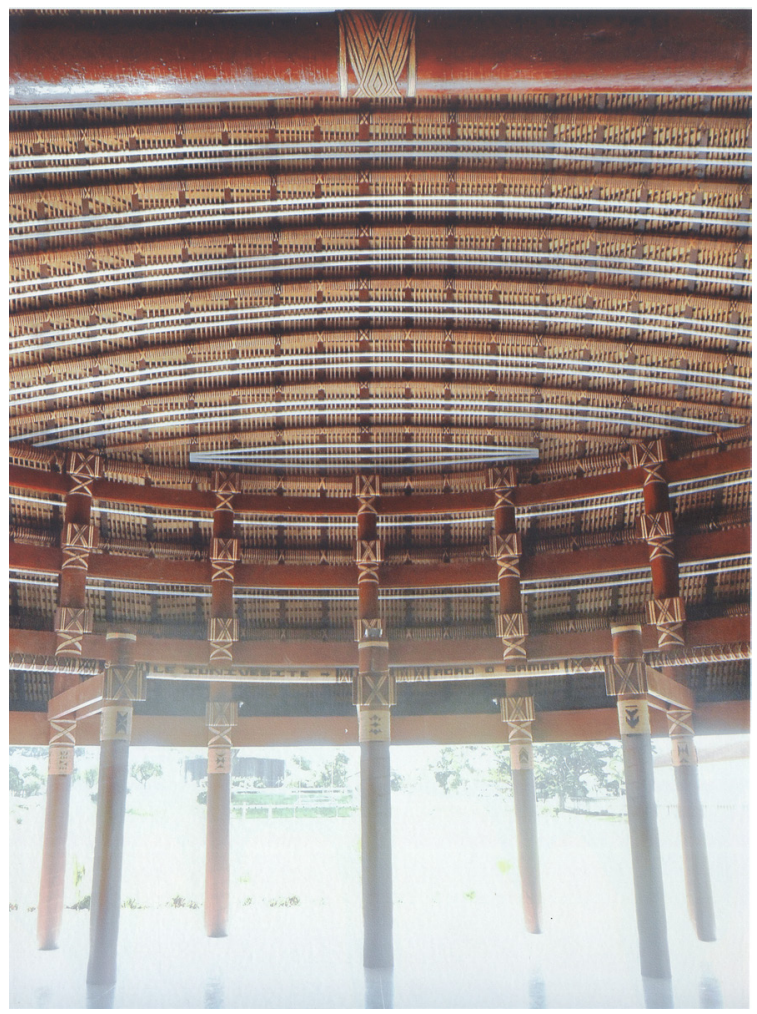

\section{Figure 28. The interior lashings and construction details of the fale at the National University of Samoa}

Source: Photographer Nikki Sloan, 2013.

One of the distinctive features of the fale is its openness (see Figure 27). There are no walls or partitions and people can enter and exit from any side of the building. ${ }^{3}$ This embodies the idea of the Samoan family as large and extended. Just as the inner space of the house extends outwards, so does the Samoan family and its members in their social relations within the family and the wider community. The Samoan term for family is a aiga, which is made up of the extended kin. This includes uncles, aunties, grandparents and children as well as those who are not biologically related but have been adopted into the family,

3 The openness of the Samoanfale does not mean that there are no restrictions associated with family life. During family gatherings, certain areas within the fale such as the front and sides are restricted to chiefs and elders. Children are prohibited from these areas as well as untitled members. During meal times, the chief, his wife and sisters are privileged in the front part of the house while brothers with their spouses serve from the back. There are also certain taboos relating to gender relations, particularly between brothers and sisters whereby males are forbidden from entering the sleeping areas of their sisters. See Penelope Schoeffel, "The Samoan concept of feagaiga and its transformation," in Tonga and Samoa: Images of Gender and Polity, ed. Judith Huntsman, Christchurch: Macmillan Brown Centre for Pacific Studies, 1995, pp. 85-106, p. 87. 
including children and adults who have served the family well. The practice of adoption is common and is a way of maintaining and consolidating family relations. ${ }^{4}$ Collectively, the family lives together with particular and shared responsibilities. Children are raised by adults, but mostly by the female members of the family, although at most times care for babies and toddlers is done by both boys and girls and gender separation of roles at this early stage remains blurred until children reach adolescence. ${ }^{5}$ Meals are cooked by the adult men, and are shared together. The land upon which the family lives belongs to the family collectively. This land has been passed down from generation to generation. It has strong connections to past ancestors and in particular the family chiefly title. The holder of the family title is responsible as custodian of the land and the welfare of the family. The power of the title holder is not absolute, and any decision has to be collectively approved by the family members.

The openness of the fale also embodies the relation of the aiga to the village. The family is not an independent entity but an integral part of the community. The village which is the basic form of polity in Samoa is a group of extended kin. They have important historical connections which are captured in the honorifics of titles and collective genealogy of the village. Each family therefore has a say in the affairs of the village. This is expressed through the holder of the family title who represents the family in the village fono a matai or council of chiefs. The status and role of each family member thus extends beyond the boundaries of the home into the social organisation of the village. The chief, wives, sisters, untitled men and children within the kin group hold certain corresponding status and roles within the village.

The fale is thus an embodiment not only of the openness of the family but also the relational character of the Samoan person. ${ }^{6}$ Like the intricate designs of the

4 Samoans resorted to adoption for several reasons, as part of ceremonial exchange, to replenish human resources particularly when an heir failed to produce heirs, or to lay claim to higher nobility. Missionary George Turner also describes how adoption is seen as a way of accessing cultural wealth and property. For example a husband would give away his child for adoption by his sister in return for oloa or property. The adopted child was viewed as ie-toga or fine mat, and was, to the family who adopted it, a channel through which native property or ie-toga continued to flow to that family from the parents of the child. On the other hand, the child was to its natural parents a source of obtaining property from the parties who adopted it, not only at the time of its adoption, but as long as the child lived. See George Turner, Samoa a Hundred Years Ago and Long Before: A Study of a Polynesian Society before the Advent of European Influence, Papakura: R. McMillan, 1983, p. 78. Refer also to Unasa L. F. Va'a, "Samoan custom and human rights: an indigenous view," in Victoria University of Wellington Law Review (Special Issue: Human Rights in the Pacific), 40(1) (June 2009): 239-50, p. 239.

5 Penelope Schoeffel, "Daughters of Sina: a study of gender, status and power in Western Samoa," Ph.D. thesis, Canberra: The Australian National University, 1979, p. 110. Also refer to Jeannette Marie Mageo, "Male transvestism and cultural change in Samoa," American Ethnologist 19(3) (1992): 443-59, pp. 450-51.

6 Debates on the relational nature of personhood in Oceania date back to Marcel Mauss and to Maurice Leenhardt in his work among the indigenous people of New Caledonia in the 1940s which contested the notion of persons there with the West "self" amongst the Kanak people. Later Marilyn Strathern stressed that in Oceania, people had a relational conception of personhood as opposed to the individual conception of the person in the West. Holly Wardlow, among others, however, has criticised such dichotomised views 
dome framework of the house, with its interwoven rafters tied and fastened together into complex patterns with coconut sinnet (see Figure 28), the Samoan person is one who is deeply connected not only to the family, but past ancestors, the land and the community. The role and status of the Samoan woman exemplify this relational character of Samoans. Like the open fale, she is not confined to a domestic sphere, and as she grows and moves from place to place, her status is enlarged by contexts and circumstances of which she is very much aware and which she deploys strategically.

\title{
The Samoan woman: From covenant keeper, to keeper of "wealth" and house of "wisdom"
}

\begin{abstract}
According to Samoan belief, the woman is born a tamasa (sacred offspring). In Samoan theology, she is regarded as a sacred vessel of divinity with powers to attract the divine. This sacred valuation determines her status and roles within the family. She is called feagaiga which has been translated as "covenant." 7 This refers to the sacred covenant of respect between a brother and a sister which gives special honour to the sister. In this relationship, the brother is obligated to serve and protect his sister. As the sacred child, the sister's curse ${ }^{8}$ is something to be feared, hence the brother's service or tautua ${ }^{9}$ is vital and must please his sister.
\end{abstract}

of "us" versus "them" in relation to debates about personhood in Oceania and the West. She suggests the co-presence of dual modes of personhood, relational and individual. See James Clifford, Person and Myth: Maurice Leenhardt in the Melanesian World, Berkeley: University of California Press, 1982; Marilyn Strathern, The Gender of the Gift: Problems with Women and Problems with Society in Melanesia, Studies in Melanesian Anthropology, No. 6, Berkeley and Los Angeles: University of California Press, 1988; Holly Wardlow Wayward Women: Sexuality and Agency in a New Guinea Society, Berkeley: University of California Press, 2006.

7 George Pratt defines feagaiga as "an established relationship between different parties, as between brothers and sisters and their children; between chiefs and their tulafale (orators)." Pratt refers specifically to the special relationship between sister and brother, between the children of sister-brother pairs, and between chiefs and orators and heads of families. The term today is also used to refer to contractual agreements or treaties, but the older meaning in terms of a special relationship is still understood today. See George Pratt, A Samoan Dictionary, Samoa: London Missionary Society's Press, 1862, p. 118.

8 Samoans believe that sisters held the power to curse the brothers with the blight of barrenness. This is still a common belief among Samoans today. See Irving Goldman, Ancient Polynesian Society, Chicago: University of Chicago, 1970, p. 252.

9 Tautua is a central concept in Samoa, expressed in the saying O le ala I le pule o le tautua (The path to authority is service). This service is broad and applies to all forms of social and kinship relations, between brother and sister, parents and children, chiefs and their kin, etc. For the brother it can be in the form of providing food and protection for the family and for the sister in the form of making valuables like fine mats and siapo or tapa. Tautua is thus an essential criterion for the selection of appropriate holders of titles which include one who was most prominent and diligent in service. However, today tautua incorporates the ability to provide financially for the family or being able to add prestige to the family by having a highly paid government job. Thus we see those living overseas contributing cash and material wealth and those in prominent government posts holding important family titles. See Serge Tcherkézoff, "Culture, nation and society: secondary change and fundamental transformations in Western Samoa - towards a model for the study of cultural dynamics," in The Changing South Pacific, ed. Serge Tcherkézoff and Francoise DouaireMarsaudon, Canberra: ANU E Press, 2008, pp. 245-302, p. 274, online: http://press.anu.edu.au?p=90711, accessed 22 May 2014; Schoeffel, “The Samoan concept of feagaiga and its transformation," p. 104. 
The Samoan proverb, E mu mata o le tama i lona tuafafine (The brother's face burns for his sister), speaks of the service of the brother. During the day he is usually in the garden planting or fishing in the ocean. When he gets home, he prepares the meals; he serves and is usually the last to eat. The sister is focused in the fale space and is privileged in only doing light chores in and around the house like cleaning and tidying, child care and weaving. She can also move beyond the fale, doing light gardening in the vicinity of the house and fishing within the safety of the lagoons. ${ }^{10}$ This distinction between inner and outer differs from a Western segregation of feminised domestic and masculinised public spheres. In Samoa, the woman honoured as feagaiga refrains from doing heavy tasks as opposed to her brother. The Samoan gender division of labour is equal and complementary as opposed to the hierarchical nature of the Western segregation where the public is seen to eclipse the domestic.

The sister's venerated status comes with definite and serious responsibilities. In return for her brother's service, she becomes the "covenant keeper" by honouring the name of the family. She does this by maintaining her virginity. From a young age until she is married, she is under the protection of the brother, and is often not allowed out at night. The proverbial saying, o le i'oimata o le tuagane lona tuafafine (The sister is the pupil in the eye of the brother), refers to the strict surveillance by the brother of the sister. When she does venture out, especially at night, she is often accompanied by her younger siblings. The sister is also called o le pae ma le aūli which translates as "the shell and the iron" ${ }^{11}$ referring to her role as peace maker, the one responsible for the peaceful relationship and happy co-existence between the brothers or relations of the family. She is the faioa, the "maker of valuables" like ietoga or fine mats and siapo or tapa which are extremely important and essential in the operation of the socio-cultural life of Samoans. She is the taulāsea, the healer whose knowledge of medicinal herbs is vital to the health and wellbeing of the family. Most importantly she is the tausala (the ransom) or taulaga (the offering) referring to her role as the redeemer who will be able to ransom or redeem the äiga in times of dire need. ${ }^{12}$

10 In Samoa, women are not tillers of the soil or planters of crops. Their planting responsibilities are confined to plants used for medicinal purposes like herbs, as well as plants used to make items such as the fine mats, and the siapo or tapa, and plants like the candlenut used to make the lama or black soot used as ink for tattooing and for tapa print. As feagaiga, women are further removed from any manual work involved in the cultivation of the land. Refer to Aiono Fanaafi, "Western Samoa: the sacred covenant," in Land Rights of Pacific Women, Suva: Institute of Pacific Studies of the University of the South Pacific, 1986, pp. 102-09, p. 105.

11 This translation of pae was given to me by Seiuli Vaifou Temese during an interview, where she told me that this was a particular shell used by women to straighten the bark of the mulberry plant before it is used for the making of saipo. Personal interview with Seiuli Vaifou Temese, 5 April 2012.

12 The ietoga or finemat made by Samoan women were symbolic of sisters and daughters. This is illustrated in the rite of ifoga or ceremonial apology. The party offering the apology covers their heads with ietoga symbolising the protective powers ascribed to sisters. 
This brother-sister relationship of covenant and redemption is vital when the time comes in selecting the heir to the family title. At such time, the sister may claim the title herself as every family member is an heir irrespective of gender. ${ }^{13}$ However, on many occasions she gives the title to her brother as a sign of respect honouring his service. ${ }^{14}$ This however does not devalue her status as feagaiga. She still receives equal respect to that of the chief. She is seen as the se'ese'e taläluma which translates as "the one who sits in the front part of the house." In a family gathering this is her rightful place embodying her esteemed status. During important decision-making apropos family matters her opinion is highly regarded and sought after. In many cases it is the sister who has power to veto decisions of the family based on her powerful curse. The Samoan woman as sister therefore holds an honorary and sacred status within her family, which gives her important power and influence.

Within the village setting, the sisters and daughters of the local men make up the social group called aualuma (front group). ${ }^{15}$ This refers to its prestigious position within the village hierarchy, because it constitutes the feagaiga of the village. Here we see how the covenant relationship between the brother and sister is played out at the village level. Generally, there are two well-defined parallel hierarchies of distinct spheres of activities in the village known as the $n u^{\prime} u$ o ali'i or village of men and nu'u o tama'ita'i or village of women. The village of men refers to the council of chiefs while the village of women refers to the aualuma. In the village, the power of the aualuma is comparable to that of the council of chiefs. In a similar manner, they can confer rules and carry out punishments for those who breach them. ${ }^{16}$ Hence, within the social structure of the village, we see the central status of women, who maintain semi-autonomous status through the aualuma. As a social organisation, they have a powerful position, complementary to that of the council of chiefs.

The aualuma also embodies the honour and respect of the village. This is because in the past, they were responsible for guarding the virginity of the taupou or

13 In Samoa there are no commoners as everyone is an heir to a chiefly title irrespective of gender. Accordingly for a feagaiga, to claim a matai title means she has to relinquish her feagaiga-ship. This is because both statuses function as equal and complementary in terms of authority. It must also be noted that as a sister is to her brother, so is a female descent line (tamafafine) to a male descent line (tamatane). So every Samoan descent-group contains two categories of kin; the tamafafine and the tamatane. Both groups comprise female and male members, who should treat one another as though they were sister and brother respectively.

14 It must also be noted that a family has more than one chiefly title. However the main title called $s a^{\prime} o$ is the most important and is often given to the eldest in honour of his service if it has pleased the family. There are other lesser titles and these can be bestowed to other brothers or members of the family, or to one who is able to stay in the family as other brothers might move to their wives' families upon marriage.

15 Aualuma is made of two words; au (group), luma (front). Aualuma thus refers to a group of women or sisters of the village given the prestigious position of being in the front.

16 This practice is still present in several villages in Samoa where the village of women still has a strong influence. I was told during interviews that in some villages the aualuma is strong and very active. In some villages however, wives of chiefs have gained prominence over sisters of chiefs. 
virgin daughter of the village high chief before marriage to a chief of high rank. This responsibility had crucial political significance. ${ }^{17}$ The institution of the taupou was vital in linking families and villages all over Samoa through the multiple marriages of chiefs to high-ranking women. The failure of the taupou to remain a virgin would result not only in disgracing the honour and respect of the village but also in the withdrawal of the marriage betrothal. ${ }^{18}$

As we have seen, the Samoan woman as sister has a venerated status within her family and village. The situation however changes when she is married and moves to her husband's family and village. Here, her status shifts from a feagaiga to a nofotane or wife. ${ }^{19}$ In her husband's family, her status is determined by that of her spouse. This is due to the relationship of covenant between her husband and his sister. As a nofotane, she supports her husband in carrying out this service. She accompanies him to the garden during the day, and in the evening assists him in the preparation of the evening meals. In her capacity as wife, she moves out of the fale and enters what is considered the sphere of her husband. Within her husband's village, she belongs to the group known as the ava a taulele' $a$ "the wives of untitled men," who come under the direction of the aualuma. They are often referred to as o lima ma vae meaning "hands and feet" referring to their roles in doing errands when the village women get together. All this is part of their service in honouring the sisters of their husbands. For the wife, this service can be difficult but all will be rewarded when her husband becomes a chief.

Once her husband's service is honoured with the bestowal of the family chiefly title, her position is elevated to being a faletua if the title is that of an ali'i or high chief, or tausi if the title is that of a tulafale or orator. Faletua literally means "the house at the back," 20 referring to the "house" behind the main house in which food and gift presentations are prepared during family gatherings or

17 Niel Gunson, Penelope Schoeffel and Gavan Daws argue that women were crucial in the transmission of rank and the legitimisation of chiefly power in ancient Samoa. See Niel Gunson, "Sacred women chiefs and female 'headmen' in Polynesian history," The Journal of Pacific History: Sanctity and Power: Gender in Polynesian History 22(3) (1987): 139-72; Penelope Schoeffel, "Rank, gender and politics in ancient Samoa: the genealogy of Salamāsina O le Tafaifā," The Journal of Pacific History: Sanctity and Power: Gender in Polynesian History 22(4) (1987): 174-94.

18 A taupou was usually reserved to marry a high-ranking chief in order to gain status and political alliances. The aualuma therefore, guarded with care the taupou until the wedding day where a public defloration would test her virginity, a practice that was severely condemned by the missionaries, and, by the beginning of the twentieth century, was clearly abandoned.

19 Nofotane is made up of two words; nofo (to sit or stay) and tane (husband). The term can be a derogatory one given to a female married into the family if she should err in the carrying out of her duties.

20 According to Fanaafi, faletua has been translated by Samoan feminists to mean "back of the house" since that is its surface literal translation: fale means dwelling; tua means back. Yet the real meaning of the term according to her is, "the adviser that the house depends on; the backing which a matai finds difficult to do without. Likewise the primary role of the wives of chiefs is to give good advice and to be suitable counsellors to their husbands who are the collective authority of the äiga and the village." See Aiono Fanaafi, "The social status and the economic roles of the female in traditional and modern Samoan society," unpublished paper, n.d., p. 5. 
cultural ceremonies like funerals. The house at the back therefore plays a crucial role in the success of these events. Likewise the faletua is vital in the success of the high chief in carrying out his roles. She is the backing upon whom the chief depends for wisdom and advice. Thus as a faletua she is the "house of wisdom" and can influence decisions within the family and village through her husband. Tausi (to keep), refers to the orator's wife's role as keeper of the family wealth, taking care of tapa and fine pandanus mats, which are important valuables for ceremonial gift exchanges. Thus, as a wife of an orator, she is vital in keeping the good reputation of the family, as an orator's ability to speak with conviction depends on the wealth he is able to distribute. As wife of a chief, therefore, the Samoan woman ultimately assumes an influential role within her husband's family and village. Moreover, despite her lower status in her husband's family, vis-à-vis his sister, her inherited rights as a feagaiga will never be denied within her own natal family. She remains a feagaiga in her natal family regardless of where she chooses to live. A negotiation made by her natal family in her absence can never be declared valid if her consent is not given.

The roles and status of the Samoan woman is therefore open, dynamic and complex. They shift as she moves from place to place, from inside the confines of the fale to open spaces around the home, from being a sister in her natal family and village to that of a wife in her husband's family and village, and from being a wife of an untitled man to that of a high chief or orator. Her passage from "covenant keeper" to "keeper of wealth" and "house of wisdom" shows the expansiveness of women's influence and the fact that this is in no way constrained by a "domestic" sphere. Although in certain contexts there are important structural and cultural constraints on women's agency, there are always avenues in these places and spaces to assert their influence. When missionaries arrived, these spaces were more rigidly segregated as they advocated a status for women confined to the home as a wife and a mother. Thus the arrival of missionaries challenged Samoan ideals about the expansive status and high valuation of Samoan women.

\section{European missionary wives: The project to "uplift" Samoan women}

The first European missionary couples arrived in Samoa in 1836; six years after John Williams of the LMS formally introduced Christianity in $1830 .^{21}$

\footnotetext{
21 The earliest letters used in this chapter by London Missionary Society (LMS) missionary wives who worked in Samoa were found at the following libraries. The letters by Mrs. Mills are found in Archibald W. Murray's, "Memoirs of Mrs. Mills," published in the magazine The Illustrated Words of Grace, Sydney, Melbourne: Colonial Publishing Company. Both the National Library of Australia and the Mitchell Library hold parts of the series, as follows: vols 4(9)-5, 1879-1880, Canberra: National Library of Australia (NLA);
} 
During those early years, Tahitian missionary couples worked on their own, with Williams and other European missionaries from other well established missions in Tahiti and Rarotonga visiting intermittently. ${ }^{22}$ The arrival of white missionaries and their wives meant that evangelisation became far more dispersed, with the establishment of mission stations throughout the Samoan islands, where they were able to exert more direct influence. This was a strategic move to quickly spread missionaries' sphere of activities to cover the whole of the archipelago.

European missionary couples arrived with much keenness to transform Samoa into a civilised and Christian society. The wives in particular saw their role as focusing on the conversion of women. Their early impressions of the state of local women made them more determined. In one of her first letters written soon after arrival in Samoa in 1836, Mrs. Lilias Mills wrote; “The women are in a lamentable condition - slaves to the tyranny of their masters. The Gospel will soon rescue them from their thraldom." ${ }^{23}$ Mrs. Mills, like many of the early missionaries and their wives were too quick to judge the state of Samoan women. Later, writing by the missionary Archibald William Murray would correct her assessment. He wrote,

A more extensive acquaintance with heathen countries would have led Mrs Mills to form a different estimate as to the position and treatment of women in Samoa. Nowhere among the many islands, east and west, which I have visited, have I found woman so nearly upon an equality with man as in Samoa. Indeed, the treatment of women on that group was one of the most marked features of the milder type of heathenism that was found there. ${ }^{24}$

Early missionary wives however did not see this as a "milder type of heathenism," and were passionately determined to transform what they perceived as the

vols 4(1)-6(1) (1879-1881), Sydney: Mitchell Library (ML). Mrs. Day's letters are found in William Day's The Domestic Correspondence of the Rev. William Day and His Family in the Launceston Public Library, transcribed by Phillip K. Cowie, Tasmania: Launceston Public Library, 1963. A copy of this is held at the Chifley branch of The Australian National University Library. Other letters used in this chapter by LMS missionary wives are published in the LMS mission magazine The Samoan Reporter, from its first issue in 1845, Number 1 to Number 23 in 1962. Copies of this series are held at the Alexander Turnbull Library, Wellington, New Zealand. Also used was the Archive of the LMS Samoa District Committee microfilmed by the Pacific Manuscript Bureau, Canberra: The Australian National University, PMB 1278. This includes Minutes of Meetings and Administrative Records from 1851-1973.

22 The arrival of European missionary couples marked an important development in the evangelisation of the Samoans. The Tahitians' efforts were important, but they were often under the influence of local paramount chiefs who confined them under their protection and deployed them for local political purposes. 23 Lilias Mills, Apia, Upolu, to brother, England, June 13, 1836, in Archibald W. Murray, “Memoirs of Mrs. Mills," in The Illustrated Words of Grace, Sydney, Melbourne: Colonial Publishing Company, 4(9) (1880): 177. 24 Murray, "Memoirs of Mrs. Mills," p. 177. Murray's assessment was made around 1880, after spending several decades in Samoa in which he had gained a better understanding of the status of Samoan women. His view is also based on having visited other islands in the Pacific; in comparison he found the status of Samoan women greater than others. 
low state of local women vis-á-vis their masters. Upon arrival, they quickly set out to educate women. There was a clear demarcation of the roles of missionary husbands and wives. The husbands would conduct regular visits to neighbouring villages and districts while the wives worked mainly from their homes. This separation was in terms of their distinct roles, the husband dealing in an enlarged public sphere while the wife was clearly confined to the private, focusing on her domestic and maternal roles.

Initially missionary wives conducted classes from their homes. Their schedules were intense, with classes running all week except Saturdays. The first lessons were basic literacy and catechisms on biblical knowledge and Christian principles. Soon, faasā (forbidding) classes were introduced for women who had decided to relinquish heathen customs. The methods included reading a portion of scripture, which was explained and practised in the catechism. Samoan practices like poūla or night dance, tattooing, polygamy, taupou (cult of virginity) and arranged marriages crucial to political alliances were prohibited. ${ }^{25}$ Instead missionaries encouraged monogamous marriage and the idea of a nucleated family consisting exclusively of father, mother and their children. Samoan women were taught to be proper Christian wives to their husbands and good mothers to their children. Special classes were conducted to teach how to best do domestic chores and how to bring up children. Mrs. Day wrote to her son in 1843,

$[\mathrm{P}]$ apa and mama have a very large class of mothers, that they may get knowledge how to bring up their children. For instance they have no idea of the cleanliness we are accustomed to in England; but it is pleasant to see them now, with their bodies clean and shining; the only clothing they generally wear is a piece of cloth about their loins. ${ }^{26}$

Modesty was one of the first lessons that missionary wives attempted to instil in Samoan women. The nakedness of Samoan women exposing their breasts was abhorrent to many missionaries and their wives. When Williams first arrived he wanted such nakedness banned. On seeing the lack of progress in this area on his second visit in 1832, he questioned his Tahitian teachers but they replied,

They could not induce them to cover their persons of which they are exceedingly proud especially their breasts which are generally very

\footnotetext{
25 Missionaries and their wives were adamant about prohibiting customs that were associated with "sex" which included the poula or night dance. Williams described this form of dance as a "charged sexual expression of human nature." See John Williams, Missionary Enterprises, London: John Snow, 1840, p. 89. Other practices like tattooing and traditional marriage which also involved sexual practices were greatly condemned by missionaries.

26 Mrs. William Day, Sagaga, Upolu, to her son, England, April 5, 1843, in William Day, The Domestic Correspondence of the Rev. William Day and His Family in the Launceston Public Library, transcribed by Phillip K. Cowie, Tasmania: Launceston Public Library, 1963, p. 52.
} 
large. They are continually wishing the teachers wives to lay aside their garments \& "faasamoa" ( $\left.f a^{\prime} a-S a \bar{m} o a\right)$ do as the Samoan ladies do, gird a shaggy mat round their loins as low down as they can tuck up the corner in order to expose the whole front \& side of the left thigh anoint themselves beautifully with scented oil, tinge themselves with turmeric put a string of blue beads round their neck \& then faariaria ( $f \bar{a}^{\prime}$ alialia) walk about to shew themselves. You will have, say they, all the Manaia (mānaia) the handsome young men of the town loving you then. ${ }^{27}$

When Williams left in 1832 he told Malietoa Vaiinupō, the most powerful paramount chief in Samoa at the time, of the things that should be forbidden to Christians. They included war, theft, lying, cheating and dancing naked. Missionary wives thus assumed the responsibility of covering up Samoan women. One of the early lessons they taught was in millinery and dressmaking. Mrs. Mills wrote in 1837, "My trouble will be repaid by seeing the female body covered and the bunch of leaves laid aside." 28

Early missionary wives soon celebrated the success of their work and the enthusiastic response of Samoan women in attending their schools. This was often expressed in their letters as well as school "progress reports" that filled the pages of the missionary newspaper The Samoan Reporter in the 1840s and 1850s. Mrs. T. Bullen wrote in 1946, "Our female boarding school contains 32 pupils. They appear to prize the privileges they enjoy, and their progress in the various branches of education is, to the whole, satisfactory." ${ }^{29}$ This eagerness to learn spread to neighbouring villages and districts; some came from miles to be taught. Young girls were eager to learn and soon made good progress. Girls who became fluent in Samoan literacy were then used as monitors to teach others. Older women were desirous but were slower to learn.

The enthusiasm of Samoan women for collective education however, might be attributed in part to the pre-existing collectivity of women in social organisation. As mentioned, women in their status as sisters form the powerful and extremely well-organised aualuma. Conversion was communal and thus once the leaders of the aualuma decided to convert, all women including their daughters followed suit. Early conversion in Samoa is often attributed to the influence of paramount chiefs like Malietoa. This largely ignores the power of Samoan women in conversion. Consider this account by Williams on his second visit to Samoa in 1832,

27 Richard M. Moyle, The Samoan Journals of John Williams 1830 and 1832, Canberra: ANU Press, 1984, p. 117.

28 Mills, Apia, Samoa, to her brother, 24 April 1837, in Murray, “Memoirs of Mrs. Mills," p. 304.

29 Mrs. T. Bullen, “Mrs. Bullen's School," The Samoan Reporter, 4 (September 1846): 2. 
Just as our conversation was about to end we were interrupted by the appearance of a line of females following each other in goose-like procession about seventy in number each bearing something in her hand. On entering the house ... she (the leader) had heard that I had come up to the settlement and fearing that I might not reach so far as hers she had collected the Christian females together and come to pay her respects to me as the Chief to whom she was indebted for the knowledge of Jehova. ${ }^{30}$

On this occasion, Williams witnessed a powerful demonstration of the unity and influence of Samoan women within the village. Mrs. Day also witnessed this in 1844,

This day all the Ladies of Sagaga came with their alofa (love gifts) to the Faifeaus [Missionaries] with a head of taro and one fish, each of them dressed alike, with a pretty native piece of cloth put over the shoulders and the bosom with a very fine mat put on so as to make a train behind, with a wreath of flowers round the head: they marched up to the front of the house singing a pretty native song. At the end of the procession one of the Ladies got up and made a suitable speech to the gentlemen. I could not help shedding tears. ${ }^{31}$

Samoan women were thus desirous of the new religion. Learning to read and write was linked to accessing the knowledge of the Europeans. Samoan women saw the values in accessing new skills, even of domestic duties, as beneficial to them. The wives of missionaries were seen as the source of this new knowledge.

From the beginning, the enthusiasm of Samoan women coupled with the resolve of missionaries and their wives to uplift women to their standards of the idealised Christian women, led to initial success in school attendance. However, as they soon realised, things were not as easy as it seemed, and conversion was largely nominal at this early stage. As the project to uplift Samoan women continued, the local context in Samoa provided new challenges that would complicate the work of missionary wives.

\section{The burden of the fale and domestic duties}

Missionary wives began their mission from the domain in the home where women flocked in order to observe and learn. The emphasis was on the "home"

30 Moyle, The Samoan Journals of John Williams, p. 146.

31 Mrs. William Day, Upolu, to her son, July 7, 1844, in Day, The Domestic Correspondence of the Rev. William Day and His Family, p. 70. 
or what Diane Langmore called the "object lesson" 32 for the local women, where the missionary wife would perform her domestic duties as a respectable wife and ideal mother. Yet initially the Europeans lived in Samoan fale given to them by village high chiefs. These houses which were open and usually at the centre of the village, provided a highly visible stage for the inquisitive audience of Samoans. This being a stage also hindered such performances.

First, early missionary wives struggled to deal with the different environment and the strange behaviour of the locals. They complained about the heat, humidity, insects and the lack of comfort in their living quarters. The open fale, exposed them not only to the harsh physical elements they were not accustomed to but also to the prying eyes of locals. Mrs. Mills once complained, "All the time my hands are busy with some domestic employments, and no one attempts to assist me in this. They all stand wondering at everything I do." ${ }^{13}$ She went on to write, "Often when my house has been full of noisy Samoans I have sighed for a quiet corner where I should shut my door and be alone." 34

The mission home, an important exemplar for instilling a civilised way of life to the natives soon became a place of discomfort as missionary wives constantly complained about the lack of privacy and expressed yearning for the comforts of an English home. Feelings of "homesickness" and yearnings for home comforts were perpetuated by the lack of letters or news from their relatives back "home." Communication was hard at this stage as the mission ship, the Camden, only visited England once every two years and thus news of relatives and of broader British affairs did not reach them for months or even years.

Missionary wives also suffered greatly from diseases such as erysipelas ${ }^{35}$ and dropsy ${ }^{36}$ which caused them to be bedridden for weeks. Many of their letters expressed worry over their lack of usefulness to the mission project due to prolonged sickness. Some wrote of their anxiety that they would die without having achieved their mission. Some suffered from loneliness and mental depression. Such laments and ailments however, were often suppressed and seen as sinful, an obstacle to their calling to save the lost souls around them. As Mrs. Mills wrote, "The want of civilised, or the want of Christian society, the want of many precious ordinances I feel much; but when I put them in the balance with the wants of the souls around me, and the claims of my Saviour, the latter preponderate." ${ }^{37}$

32 Diane Langmore, "The object lesson of a civilised, Christian home," in Family and Gender in the Pacific, ed. Margaret Jolly and Martha MacIntyre, Cambridge: Cambridge University Press, 1989, pp. 84-94, p. 86.

33 Mills, Upolu, to her sister, 24 June 1836, in Murray, “Memoirs of Mrs. Mills," p. 178.

34 Mills, Upolu, to her brother, 25 September 1836, in Murray, “Memoirs of Mrs. Mills," p. 210.

35 Erysipelas is a type of skin infection with symptoms such as blisters, fever, shaking and chills.

36 Dropsy is characterised by swelling of the body caused by a build-up of fluids in the body cavity due to internal organ failure. It is caused by exposure to poor water conditions, excessive use of salt and improper diet.

37 Mills, Upolu, to her brother, 25 September 1836. 
In addition to their predicament was the increasing burden of both domestic and mission duties. Missionary wives were often regarded as "self-sacrificial helpmates" to the pastoral endeavours of men. ${ }^{38}$ Their ongoing responsibilities included the instruction of village girls and women, as well as their customary household tasks. As their schools grew in number, the latter became increasingly burdensome. Servants and nannies were thus employed to attend to their domestic chores like washing, ironing and child care. Although they complained about Samoan women's lack of knowledge about domestic work, this was an option they had to choose in order to commit time to their schools.

Furthermore, missionary wives were in constant worry over their children's intellectual and spiritual development. Many were anxious about their education, as well as their spiritual wellbeing in a "pagan" environment. ${ }^{39}$ Missionaries' children were often vulnerable to illnesses in the tropics and there was the constant fear that if their children died, their souls would not be saved. Hence they were vigilant in observing signs of spiritual rebirth in their children. Mrs. Mills wrote of her son, "Since the end of March our dear William has been ill, and many a pang have I felt, as well as many a tear I have shed, chiefly on account of his soul. I have not yet had the evidence that he is born again, and this is the reason of my distress." 40 She also wrote of her children, "They seem to me so far behind what children of their age are at home and this is one reason why I am so anxious they should be where they are likely to improve more rapidly." ${ }^{41}$ According to Murray such anxieties were common among missionary wives. Many feared that Samoa was not a place to raise their children, for fear of contamination. Murray wrote, "If they are to be saved from moral contamination, and fitted for positions of usefulness and respectability in life, the question of their removal to a civilised land must be entertained." ${ }^{42}$

Thus on 2 December 1846, ten years after many of these women settled in Samoa, the mission ship the John Williams on its return voyage to England, witnessed a kind of a mass "evacuation" of many of the missionaries' children. The farewell was a sad occasion and many wrote about the intense sorrow they felt when having to part with their children. Murray wrote,

\footnotetext{
38 Sharon W. Tiffany, "Introduction: feminist perceptions in anthropology," in Rethinking Women's Roles: Perspectives from the Pacific, ed. Denise O'Brien and Sharon W. Tiffany, Berkeley: University of California Press, 1984, pp. 1-12, p. 10.

39 These concerns were often shared in "maternal meetings" where the wives discussed and prayed over their children's early conversion to God. A special hour was also dedicated to the supplication of their children. Mrs. Day wrote to her son that "At our last maternal meeting all the eldest children were mentioned in a special manner for early conversion to God, and you my darling Benjamin are one of them. Our hour for that purpose is every Tuesday night any time from seven to nine." See Mrs. William Day, Upolu, to her son, July 7, 1844, in Day, The Domestic Correspondence of the Rev. William Day and His Family, p. 70.

40 Mills, Personal Journal, 12 May 1846, in Murray, "Memoirs of Mrs. Mills," p. 371.

41 Mills, Upolu, to her sister, 3 June 1845, in Murray, "Memoirs of Mrs. Mills," p. 290.

42 Murray, "Memoirs of Mrs. Mills," p. 290.
} 
And the nature of that scene, only they who have passed through it can fully understand. Oh! The anguish of the parting moment! The writer has had personal experience of it; and he has been a sympathising witness of the scenes he describes on many occasions. In as far as his experience goes, there is but one thing that inflicts a deeper woundviz., separation by death. And when the sad crisis is past, when the last fond words have been spoken, the last embrace given, the last lingering looks exchanged, and the ship has stood away out to sea, and been watched till all trace of it has been lost in the distance - what then! Ah! What then? ${ }^{43}$

Tragically many of these missionaries and their wives never saw their children again. Ironically some of the children died in England soon after.

Missionary ideas of physical and moral contamination were thus a major factor in the "evacuation" of their children. It must be noted that many of them came with a perception of the Pacific not as "a paradise" where "noble savages" live in perpetual harmony as popularised by eighteenth-century voyage accounts, ${ }^{44}$ but as a place of savagery and sexuality which needed to be rescued from evil customs and practices. Exposing their innocent children to this world was thus seen as detrimental to their physical and spiritual growth.

Overall, the idealised project of domesticity was clear in the efforts of early missionaries and their wives. However, there was much paradox and poignancy in this project. The portrayal of missionary wives as ideal mothers and wives was often hampered by local conditions that made their early experiences extremely dangerous and uncomfortable. Their discomfort with the open fale reflects a clash of ideals about domesticity. This was further complicated by the employment of servants and nannies to perform their domestic duties, and by sending their children back "home." As they taught Samoan women how to become proper wives to their husbands and proper mothers to their children, they themselves were living very different lives, often as full time teachers. This paradox continued with the establishment of more formal education for the wives of Samoan students at Mālua Seminary in 1844 and for girls at Papauta boarding school in 1892 .

\footnotetext{
43 Ibid., p. 405.

44 Refer to Serge Tcherkézoff, First Contacts in Polynesia: The Samoan Case (1722-1848) Western Misunderstandings about Sexuality and Divinity, Canberra/Christchurch: The Journal of Pacific History/ MacMillan Brown Centre for Pacific Studies, 2004; Margaret Jolly, “Desire, difference and disease: sexual and venereal exchanges on Cook's Voyages in the Pacific," in Exchanges: Cross-cultural Encounters in Australia and the Pacific, ed. Ross Gibson, Sydney: Museum of Sydney/Historic Houses Trust of New South Wales, 1996, pp. 187-217; Jolly and Lenore Manderson, "Introduction: sites of desire/economies of pleasure in Asia and the Pacific," in Sites of Desire, Economies of Pleasure: Sexualities in Asia and the Pacific, ed. Lenore Manderson and Margaret Jolly, Chicago: University of Chicago Press, 1997, pp. 1-26; Margaret Jolly, "Imagining Oceania: indigenous and foreign representations of a sea of islands," in The Contemporary Pacific 19(2) (2007): 508-45; Margaret Jolly, Serge Tcherkézoff and Darrell Tryon (eds), Oceanic Encounters: Exchange, Desire, Violence, 


\section{Malua and Papauta: Shifting boundaries of domesticity}

The establishment of Mālua was a strategic move to extend mission influence by providing a pastor and a wife for each village in the country. In Samoa, villages were autonomous, and thus the local context demanded that each village had its own congregation with its own missionary and wife. This meant that the initial establishment of mission stations which incorporated several villages and districts was doomed to fail. Mālua was thus set up to cater for the increasing need for trained pastors. The hope was that in a restricted environment, young Samoan men and their wives would be moulded into Victorian models of the perfect gentleman and lady, to be imitated by their Samoan counterparts in the villages.

The architecture and design of Mālua was constructed in order to serve this purpose, instilling English ideals of a civilised community. The compound was a replica of an English village, with limestone cottages lined in perfect order, surrounded with gardens and rolling green lawns enclosed with finely trimmed hedges. Samoan students and their families were introduced into a novel way of life, living in box-like cottages with a strict daily routine under the watchful eyes of missionaries. Missionaries and their wives lived in larger buildings with the trappings of an English home. Mālua was now a striking contrast to life back in the villages. No longer exposed to village life, wives of missionaries at Mālua felt more comfortable in their private dwellings away from open fale. Coincidently, missionaries and their wives in the villages were also living in European-styled houses. Many of the missionary wives expressed elation at finally moving into their newly built limestone houses. The discomfort they once felt due to the lack of privacy of Samoan fale was now replaced by the comfort and security of their walled-up homes. The stage was now closed off and the foreign example of the large European home with huge limestone walls and glass windows now loomed large in the village.

The LMS Samoan mission saw the importance of training the wives of students at Mālua and in 1864, passed a resolution to give priority to the entrance of married couples rather than single men. In the words of missionary George Turner, "If we have the choice of two we reject the single man, and admit the married couple, for the simple reason that the wife needs education as well as her husband and, when instructed, is a great blessing to her sex in the village where he may be called to labor." ${ }^{45}$ Missionary wives were thus responsible for the training of students' wives. The basic curriculum consisted of literacy, 
arithmetic, biblical instruction, needle work, geography and astronomy. ${ }^{46}$ The expanded curriculum reflects not just domestic work but the more expanded role of pastors' wives as teachers to women in the local village. The establishment of Mâlua was a great success and, by the end of the nineteenth century, the clergy in Samoa was largely indigenous. Graduates of Mālua and their wives took over the roles of foreign missionaries and their wives in villages altering the outlook of the mission. Foreign missionaries were still at the helm, but the day to day activities of the Church in villages were now mainly in the hands of Samoan teachers and their wives. Consequently, the localisation of the Church and the indigenisation of the clergy meant that evangelisation was now deeply ingrained in Samoan local customs and suffused with local structures and practices. This was deeply distressing for the missionaries as they complained about the persistence of heathen practices after decades of efforts to transform the Samoans. Missionary John Marriot for example wrote in a published sermon in the Samoan Church magazine O le Sulu Samoa, "I am shocked to hear various stories which show that many old practices are still alive, they are bad and they should be called pagan practices." 47 Then Marriot went on to condemn practices such as the adoption of children, of girls being prepared as taupou and couples not being properly married or looking after their children. Moreover, he suggested that their fale should have rooms; that boys and girls should sleep separately and that it was a shameful thing for them to sleep together. From these later published accounts, we see that the ideals propagated by missionaries often fell on deaf ears and that Samoan ideas about kinship and the roles of women endured for decades. Marriot's suggestion for houses to be partitioned off with closed rooms directly conflicted with the open and extended nature of the Samoan äiga, as embodied in the openness of the fale.

In 1887, a commission led by Sir Albert Spicer on behalf of the LMS directors visited Samoa where he noted a concern about the lack of progress in the project of evangelisation. Of particular concern was the state of Samoan women. As Hilda E.A. Small observed, "Although in Mālua the wives of the students were being taught, the women of the villages were ignorant and degraded." ${ }^{48}$ On his return to London Spicer urged the directors to establish a college for the formal training of Samoan girls in the Christian life. Valesca Schultze and Elizabeth Moore, two single missionary women, then took on the task of establishing these inaugural schools for girls in Samoa. Papauta Girls' School was established

46 Valerie Margaret Carson, “The Samoan mission seminary 1844-1884: a study of the means of furnishing teachers in Samoa for educational and religious outreach by the London Missionary Society members in the nineteenth century,' M.A. thesis, Wellington: Victoria University, 1983, pp. 117-21.

47 O le Sulu Samoa, July 1896, p.231. (I have used my own translation of the sermon excerpt here.)

48 Hilda E.A. Small, Papauta: The Inland Rock, 1892-1967, Auckland: Pelorus Press, 1967, p. 9. 
in 1892 in Upolu and Atauloma Girls' School in 1900 in Tutuila. The vision of the founders of these schools can be summed up in the words of the German missionary woman Valesca Schultze, who wrote in 1892,

I see a day in the distance when there will be a new generation of Samoan mothers, who will have cast behind them those bad, low and degrading customs, whose highest ambition will be to bring up their children in the nurture and admonition of Christ, and so be the means of raising the whole Samoan nation to a higher and purer standard of Christian life. ${ }^{49}$

The establishment of Papauta and Atauloma saw a more ambitious approach to educating local women in a much more confined and controlled environment. The schools provided a new pattern of living for girls but continued to propagate the domestic emphasis on women as mothers and wives in order to "raise" the Samoan nation. The range of subjects taught included arithmetic, hygiene, physiology, composition, music and singing, needle work, craftmaking and English. ${ }^{50}$ Young girls were taken from the villages to be trained with the purpose of one day becoming role models in local villages. Often the first educated women in villages were the graduates of Papauta and because of this, they "were sought after as wives for aspiring pastors and teachers." ${ }^{11}$ In 1925, the Samoan District Committee encouraged single students of Mālua to find wives at Papauta. ${ }^{52}$ Thus Papauta eventually became a breeding ground for wives of Samoan pastors. More than 70 percent of pastors' wives from the late nineteenth to the latter half of the twentieth century were ex-students of Papauta. ${ }^{53}$ This created a special relationship between these institutions which is summed up in the words of a song composed by Mālua students for the centenary of Papauta in 1992. I have translated the first verse here:

The kingfisher flies, but continually yearns for the river,

Just like Papauta, which was born out of Mālua.

That is why my memory of you will never fade,

I have come to celebrate with you.

Ladies of the Rock, my darling,

Out of my rib you were created by God.

Forget not Jerusalem, the land where our covenant was made.

49 Valesca Schultze, Report of Female Education, South Sea Records, 1894, cited in Elizabeth Roach, "From English mission to Samoan congregation," Ph.D. dissertation, New York: Columbia University, 1984, p. 96.

50 Evelyn Downs, Daughters of the Islands, London: the Livingston Press, 1944, p. 73.

51 Charles Forman, "Sing to the Lord a new song: women in the churches of Oceania," in Rethinking Women's Role: Perspectives from the Pacific, ed. Denise O'Brien and Sharon W. Tiffany, Berkeley: University of California Press, 1984, pp. 153-72, p. 159.

52 Samoa District Committee, Minutes of Meeting, London Missionary Society (LMS), May 20-30, 1925, London Missionary Society Administrative Records (1851-1973), microfilmed by the Pacific Manuscript Bureau, Canberra: The Australian National University, PMB 1278.

53 Fineaso T. Samuelu Faalafi, "An historical survey of the changing role and status of Samoan women," B.D. thesis, Suva: Pacific Theological College, 1982, p. 50. 
The words of the song reflect not just the close bond between the two schools, but the emphasis on Papauta as a place where girls were trained for the purpose of becoming suitable wives for Samoan pastors. With this strong emphasis in mind however, a significant paradox was evident in the introduction of a new figure; the single and unmarried missionary woman in the form of its founders, Ms Schultz and Ms Moore. As the establishment of Papauta and Atauloma aimed at training future wives and mothers, paradoxically these missionary women portrayed a vastly different idea of woman as single, independent and professional.

Another significant change in the education of girls was also apparent in Papauta with the incorporation of traditional skills and knowledge. An example was the inclusion of "weaving mats and baskets, sewing thatch or making coconut leaf blinds for the Samoan dormitories, stamping bark cloth, carving new patterns, or cutting buttons and spoons from coconut shell." ${ }^{14}$ The girls were also involved in gardening and fishing expeditions, activities to which they were accustomed in village life and in their homes. In compliance with Samoan custom, men were also employed to prepare and cook their food. However, girls were also taught cooking and baking using European methods. ${ }^{55}$ The change in curriculum at Papauta was perhaps due to the influence of Samoan pastors and their wives who came to dominate the mission church at the time as well as a change in the approach of European missionaries who now saw the importance of maintaining traditional knowledge and skills.

A far more important development in Papauta was the training of girls in feminised professions such as teachers, nurses and secretaries. In 1919 the Medical Department of Samoa commenced the training of nurses with girls from Papauta. ${ }^{56}$ In May 1923, three girls from Papauta entered Apia Hospital as probationers. At the same time, girls at Atauloma underwent a similar program. ${ }^{57}$ Coinciding with the setting up of women's health committees in the 1930s, Papauta was used as a base for work amongst village women and therefore organised welfare services through the establishment of women's health committees. ${ }^{58}$ In 1938, the Educational Department of Samoa also established Samoa's Teachers' College with girls from Papauta amongst its founding students. ${ }^{59}$ By the midtwentieth century, typing and shorthand became popular subjects at Papauta, with many of its graduates leading the way as employed typists and secretaries

\footnotetext{
54 Downs, Daughters of the Islands, p. 30.

55 In contemporary Samoa, men still cook in the traditional way in outdoor kitchens but with the introduction of gas stoves and electric ovens, women are now doing lighter cooking inside the houses. Traditionally all meals were cooked in outdoor ovens.

56 Samoa District Committee, Minutes of Meeting, LMS, 3-12 June 1919.

57 Samoa District Committee, Minutes of Meeting, LMS, 21 May 1923.

58 Norman Goodal, A History of the London Missionary Society, 1895-1945, London: Oxford University Press, 1954, p. 363.

59 Peggy Fairbairn-Dunlop, Tama'ita'i Samoa: Their Stories, Suva: Institute of Pacific Studies, University of the South Pacific, 1998, p. 68.
} 
in government and church departments. ${ }^{60}$ Papauta reached the height of its influence between the 1920s and the 1940s. The school was well respected and highly regarded, and it was considered an honour for many Samoan families to have a girl from their family educated there. Papauta thus ushered in a new type of woman in Samoa; one who was well educated, highly skilled and able to work professionally. The school allowed women opportunities in the workforce, and to have a career, earning a living on their own, something that was quite a novelty for Samoan women.

But these women would have a far greater impact on women at the village level where, as wives of pastors they were influential in the setting up of women's fellowships and health committees. These women's groups led to the amalgamation of women in the village blurring the distinction between sisters and wives. As mentioned, Samoan women as sisters or feagaiga held a highly esteemed status in the social organisation of aualuma vis-à-vis their brother's wives. This amalgamation however, led to the increasing influence of wives of pastors in the village who became leaders of these groups, and the gradual rise of the wives of chiefs who were now able to sit together with the sisters of the village. The high status of women as sisters was thus challenged and the brother-sister relationship which was so important to the traditional structure of Samoan society was now confronted by the increasingly dominant relationship of husband and wife.

Overall, the establishment of formal institutions like Mālua in 1844 and Papauta and Atauloma in the late nineteenth century continued to exemplify the paradox in the project of domesticity. The shift from the homes of missionaries as places of learning to seminaries and boarding schools for girls, saw the shift of missionary wives from a private to a public sphere reflecting a shifting image of the missionary woman not purely as a wife and mother, but as a professional woman. The introduction of single missionaries at Papauta and Atauloma continued to further this dramatic move to a missionary woman as an independent person working largely in the public sphere. As these institutions continued to ostensibly propagate the dominant emphasis on woman in the domestic sphere, paradoxically these single missionary women were exemplifying a very different idea of "woman." Ironically, Atauloma was eventually closed and is now just a relic of LMS activities, while Papauta is on the verge of collapsing as Samoan women today no longer seek to be trained as wives or to confine themselves to feminine occupations but rather aspire to become independent professional women in the public sphere. ${ }^{61}$

60 Forman, "Sing to the Lord a new song," p. 159.

61 Papauta is seen today as old fashioned and too restricted to a range of feminine professions. Samoan women are now venturing into occupations which were once considered for men alone. Public education thus provides 


\section{Conclusion}

The evangelisation of Samoa by the LMS saw European missionaries and their wives setting particular boundaries about domesticity and the roles of women. These boundaries were promoted in their propagation of the nucleated idea of the family exclusively as father, mother and their children, as well as in the clear separation of the roles of wives from husbands and males from females; the domestic was seen as feminine and the sphere of women, while the public was seen as masculine and the sphere of men. Such boundaries however clashed with Samoan ideas about domesticity and in particular the status and roles of women. In Samoa, the more expanded view of the family and the expansiveness of the roles and status of women blurred the boundaries between what is considered domestic and public in the West. This is embodied in the openness of the Samoan fale which reflects the extended notion of the family and the relational nature of the Samoan person. Thus, the missionaries' project to uplift Samoan women was misplaced in the sense that Samoan women were already highly valued and held esteemed status. In Samoa, gender roles were complementary and equal in terms of power and status. Women's expansive roles meant that they were not confined to a domestic sphere or merely as wives, even though as wives, they still held influential power. However, the missionaries' continual stress on the role of women in the domestic sphere challenged the high valuation of women as sisters and as keepers of the covenant, resulting in the declining emphasis on the brother-sister relationship and the rise in importance of the husband-wife relationship.

The clash in these opposing ideas was evident from the start by the discomfort felt by missionary wives in the openness of the Samoan fale and their later elation at having finally moved to the comfort and privacy of mission houses. With the construction of European-styled houses and the design of Mālua, missionary wives continued to propagate these domestic boundaries even as their portrayal of the ideal woman as wife and mother was suffused with many paradoxes, such as sending their children back to England and the employment of nannies and servants to take care of their own domestic duties.

Thus, by the end of the nineteenth century, the project to transform Samoan ideas about domesticity and to uplift Samoan women was a major disappointment for the mission. But the failure of the Samoans to emulate such models was perhaps as much due to the paradoxes inherent in the lives of missionary wives as to the different values Samoans held dear in their own traditions and culture. The localisation of the Church and the indigenisation of the clergy have shown

for these and thus the decline of such institutions. It is also interesting to note that these institutions are no longer places where prospective pastors find spouses, as many students enter the seminary already married. And in cases where students are single, they are no longer pressured to find a suitable wife at these schools. 
the agency of Samoans in contesting foreign ideas. This is also clear in the role of Samoan women in Christian conversion, a fact that has largely been ignored in the history of conversion in Samoa. But, as we have seen, their collectivity as an influential and powerful social organisation was crucial in the conversion of women. Hence, there was a confluence between women's collective organisation in Samoan culture and in Christianity. This convergence not only exemplified the agency of Samoan women in collective conversion, but also in contesting the domestic ideals of missionaries. ${ }^{62}$

Significant changes were seen in the twentieth century with the introduction of single missionary women and the training of girls in feminised professions at Papauta and Atauloma. Although the schools were geared largely towards the training of women in domestic duties as wives and mothers, paradoxically they paved the way for women to forge independent careers in the public sphere and eventually opened the gateway for them to enter the masculine professions of men. The image of an independent woman was thus a significant change for women in Samoa. But a far more significant impact was seen in the role these schools had on the traditional status of women in the village particularly with the setting up of women's fellowships and health committees, which not only blurred the distinction between the status of sisters and wives, but challenged the power of the institution of the aualuma in the hierarchy of the village.

In contemporary Samoa, these contesting ideas about domesticity and the roles and status of women are continually negotiated by Samoans. Contrasting notions about the person, kinship and gender continue to be embodied in the persistence of the architectural design of the open fale, as well as the increasing presence of the enclosed structure of European houses. It is interesting that in Samoa today both these architectural forms and designs continue to co-exist reflecting how Samoans are continually negotiating between these divergent models (See Figures 29 and 30). With the rapid influence of modernisation however, traditional ideas about domesticity, gender and personhood are today being challenged more than ever by the more nucleated idea of domesticity and individuated notions of person derived from the West.

\footnotetext{
62 This is a crucial point since in many other parts of the Pacific, no such female collectivities existed prior to the formation of Christian women's fellowship particularly in the Western Pacific. Except in places where matrilineal clans or lineages prevailed, most collectivities were extremely masculine. In the history of the Samoan London Mission Society missionary wives in the Western Pacific, the Christian women's fellowship was one of the legacies of their work, particularly in places like Papua New Guinea where these fellowships still play an active role in the Church. See Margaret Jolly, "Epilogue," in Women's Groups and Everyday Modernity in Melanesia, ed. Bronwen Douglas, Oceania (Special Issue), 74(1-2) (2003): 134-47; see also Latu Latai, "E Au le Ina'ilau a Tamaitai: the history of Samoan missionary wives in the evangelisation of Papua New Guinea," M.Th. thesis, Suva: Pacific Theological College, 2005.
} 


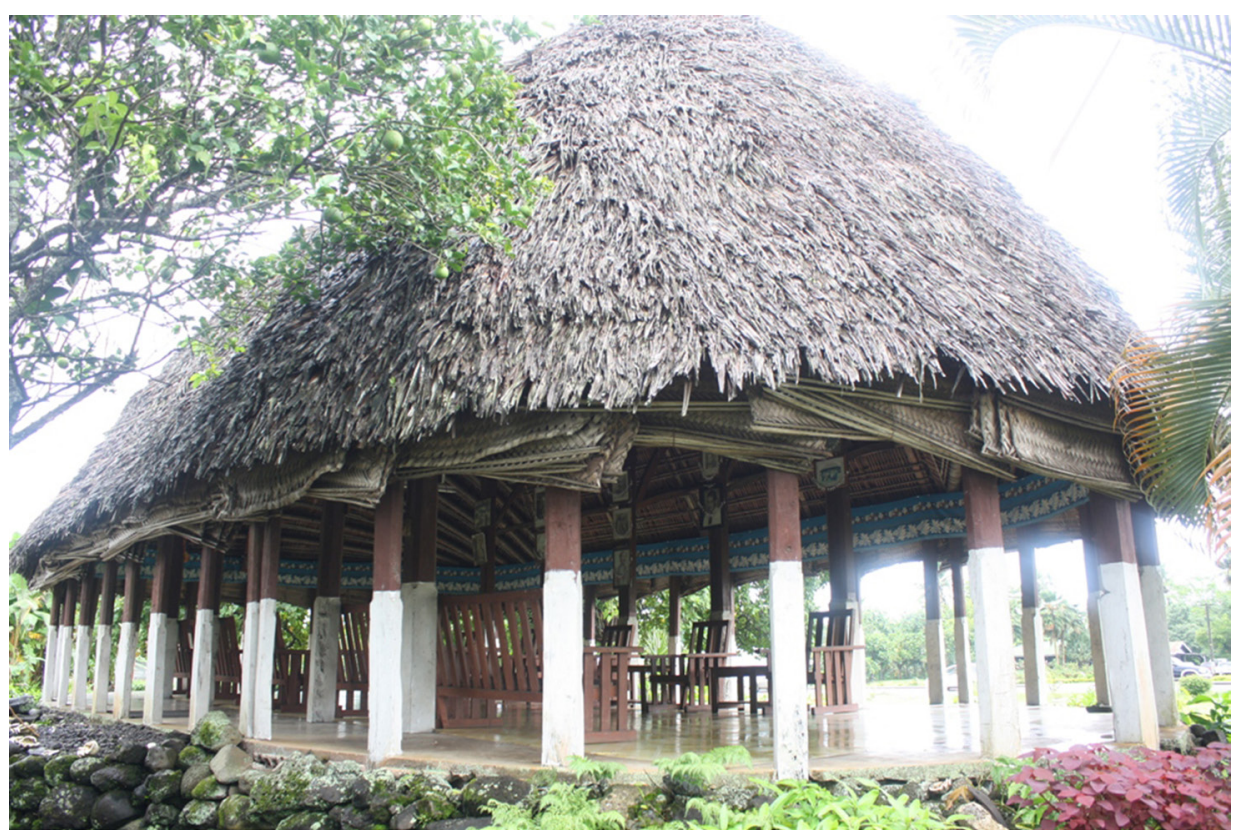

Figure 29. An old Samoan fale that still stands and is used today

Source: Multimedia Unit, National University of Samoa.

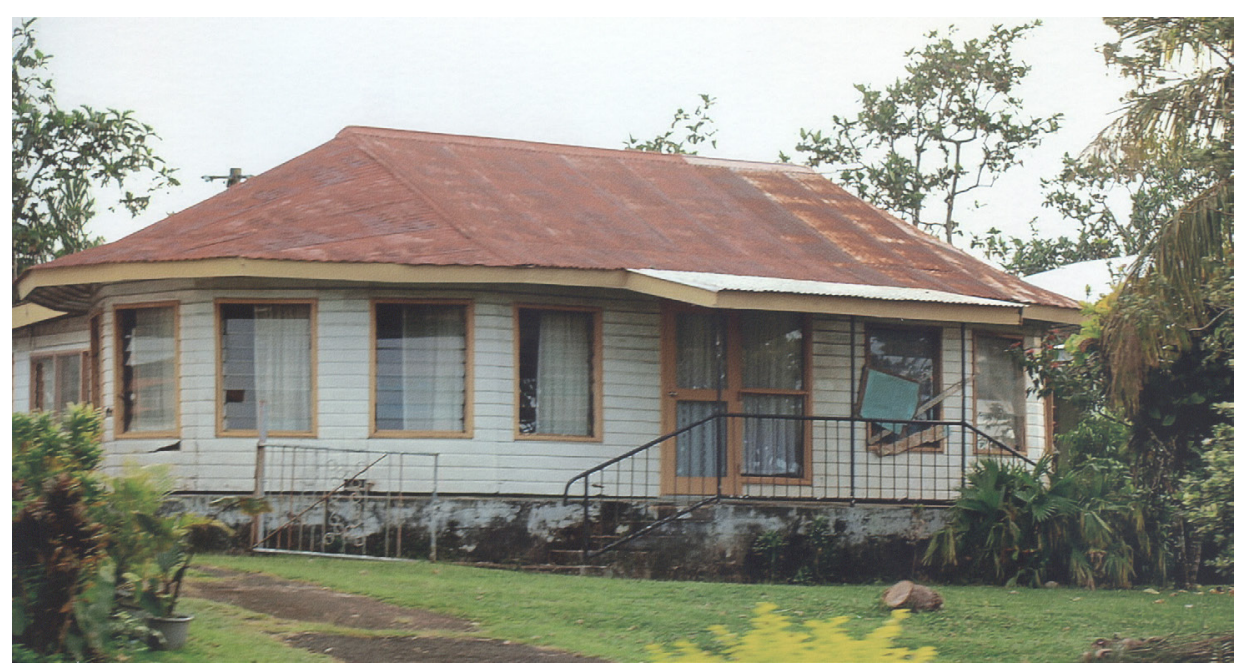

Figure 30. A Samoan fale that has been enclosed in European style

Source: Photographer Anita Latai, 2013. 


\section{Acknowledgements}

I wish to acknowledge the support of Professors Margaret Jolly and Hyaeweol Choi for urging my involvement in this volume. I particularly thank Margaret for her words of encouragement and counsel during the process of writing this chapter. I also thank Dr. Carolyn Brewer for her meticulous editing and suggestions and also those whose beautiful photographs are used in this chapter. Research for this chapter was carried out at the archives held at the National Library of Australia in Canberra, the Mitchell Library in Sydney and the Alexander Turnbull Library in Wellington New Zealand. This chapter is part of my current research on the history of Samoan missionary wives of the London Missionary Society in the evangelisation of the Western Pacific in the nineteenth and twentieth centuries. My own parents were missionaries in Papua New Guinea in the 1960s. I dedicate this chapter to their memory and to the memories of all those Samoan wives involved in missionary work. Finally, I especially wish to thank my wife Lotu and daughter Iaeli Margaret for being my source of inspiration, faith and hope which have been boundless. 
This text taken from Divine Domesticities: Christian paradoxes in Asia and the Pacific, edited by Hyaeweol Choi and Margaret Jolly, published 2014 by ANU Press, The Australian National University, Canberra, Australia. 